\title{
Facts About Ski Tourism. The Case of Ski Resorts in Romania and Bulgaria
}

\author{
Razvan Tiberiu Radu ${ }^{\star}$, Iulian Adrian Sorcaru ${ }^{\star \star}$
}

\begin{tabular}{l}
\hline \multicolumn{1}{c}{ A R T I C L E I N F O } \\
\hline Article history: \\
Accepted September 2020 \\
Available online December 2020 \\
\hline JEL Classification \\
Z20, Z32 \\
Keywords: \\
Ski tourism, Ski resorts, Tourism \\
planning
\end{tabular}

\begin{abstract}
A B S T R A C T
The research focuses on the tourism planning specific to winter sports in Romania and Bulgaria, detailing the tourism specific to alpine skiing in Poiana Brașov, Predeal and Sinaia (Romania), Bansko, Borovets and Pamporovo (Bulgaria). in Europe, along with the large concentrations of mountain resorts in the Alps, Pyrenees and Scandinavia, tourist complexes are developing in the Carpathian Mountains and the Balkan-Rhodope-Rila Mountains. That is the reason this paper wanted to highlight the comparative evolution of ski tourism in two less famous tourist destinations, but at least as interesting, related to Romanian and Bulgarian ski resorts. Another important objective of the paper was to establish the correspondence between the theoretical models of ski resorts planning and the resorts in Romania and Bulgaria.
\end{abstract}

(C) 2020 EAI. All rights reserved.

\section{Introduction}

The last decades have brought particularly important changes in the world economy, changes that have materialized in the reduction of political and trade barriers among the states, leading to significant increases in production, income and quality of life. In this sense, especially after the 1970s, there was an explosive evolution of the countries participating in the tourist circulation by increasing the number of tourists and implicitly of the trips.

The mountain, a symbol of the spirituality of many peoples, is currently one of the main holiday destinations, offering travelers the opportunity to constantly reconnect with nature through the attractiveness it manifests regardless of the calendar season. For the geographically blessed areas, tourism, through the vast human and material potential involved in its development, has acted as a stimulating factor for progress and development. The mountainous area is therefore characterized by a large concentration of tourist resources, the landform, as a support of all components of the geographical environment, representing the support of tourism activities. Therefore, the landform is considered the main component of the tourist potential of an area, this being more obvious in the mountain area. (Dinu, M., 2002)

Undoubtedly, the explosion of mountain tourism is due to alpine skiing, which will create a real "snow industry" through the "myth of white gold". (Ciangă, N., 2015)

Originally practiced in Scandinavia, the winter sport of skiing was introduced to France by Henry Duhamel, who introduced skiing to the garrison at Briançon (near Chamrousse), thus extending this practice to the French Alps and later throughout the Alpine region. Many voices say that South East Europe is developing more and more, redefining itself as the center of the so-called New Europe, the reason for the states in this area are expected to become major international destinations. (South East Tourism, https://investingintourism.com/southeast-europe-tourism/)

In 2018, Romania and Bulgaria, along with other SEE countries (Albania, Bosnia and Herzegovina, Bulgaria, Croatia, Montenegro, Northern Macedonia) received over 44 million international tourists, representing a 64 percent increase in international tourism in last five years.

Following the coastal areas, the mountain regions in SEE countries offer tourists the opportunity to engage in a variety of forms of activities throughout the year, from ecotourism and cultural tourism and heritage to hiking and adventure and winter sports.

Winter sports generate a tourist flow of approximately 330 million visitors who return revenues of up to $\$ 55$ billion annually, being practiced on all five continents. Skiing is one of the main winter activities, with the entire SEE region benefiting from more than 120 established ski resorts and over 850 kilometers of ski slopes. Moreover, SEE countries have growing economies, and business tourism in mountain regions is a significant market for the entire tourism industry in the region. 


\section{Literature Review}

Tourism as a phenomenon specific to the contemporary era, began to materialize as a separate field only in the second half of the nineteenth century, when the first attempts to define and characterize specific notions appeared. At the etymological level, it is considered that the term "tourism" comes from the English "to tour", to travel, thus having the connotation of trip. In this sense, "travel or leisure stay were inseparable from the notion of tourism. (Susanu, I.O., 2007)

The socio-economic phenomenon associated with tourism has been consolidated on the old European continent since the 1880s, the first definition belonging to E. Guy Teuler who claims that tourism is "a phenomenon of modern times, based on increasing the need for health and change of the environment, of cultivating the feeling of receptivity to the beauties of nature ... result of the development of trade, industry and the improvement of means of transport". (Cândea, M., Erdeli, G., Simon, T., Peptenatu, D., 2003)

Currently, according to the definition given by the World Tourism Organization (WTO), tourism includes who travels and resides for a period of less than one year outside his normal living environment, for relaxation, business and other purposes. (Tribe, J., 2016)

The type of tourist activity allows the structural differentiation of this socio-economic phenomenon, so that researchers can better understand the emergence and development of the tourist phenomenon in accordance with the evolution of society in a specific territory. In general, types of tourism are based on certain criteria, such as "purpose, destination, duration, dynamics [...] a mode of production or a type of economy, a tourist practice, a habitat, a human community with its specificity, in terms of motivation ". (Sochircă, V., Iațu, C., 2013)

Swizewski C. and Oancea D., (1977) distinguish three major categories of tourism types: structural (mountain, sports, cultural, commercial); dynamic (hiking, traffic, transit); stationary (with short, medium, long stay). Cataloged by the present specifications as a form of structural tourism, mountain tourism comes from the geographical environment of the mountain, which has always been, thanks to the greatness of its landscapes, an attraction for tourists.

The economic development, manifested by the diversification of the means of transport has fundamentally influenced the planning of the tourist regions. The tourist resort, a fundamental concept of research in the field of tourism, is "a locality and/or area that has a set of elements of tourist attraction and is equipped with accommodation, food and leisure, as well as other tourist facilities at the service of tourists for a certain period of time ". An example in this sense can be represented as follows: the mountain resort is in fact the locality (and the region) located at the foot of a mountain, which has those areas that allow the practice of winter sports (resources) and specific facilities to make this efficient (infrastructure). In the literature, the tourist resort is defined as "a space characterized by the predominance of tourist and leisure activities (mono-functionality) - creative ex nihilo of this place, the seasonal nature of those activities, an accommodation capacity of the non- resulting permanent population, as well as the presence of a permanent population".

A tourist resort will always have a tourist resource, such as seaside, mountain, city, village, etc. and will be accessible to tourists by a road, rail, air and sea transport network. At the same time, a tourist resort will include accommodation structures, such as hotels or campsites, etc., shops, restaurants and tourist facilities, such as ski slopes in winter sports resorts. In the mountains, the attractive landscape potential is doubled by the climatic component, the snow, with an increasing duration, directly proportional with the altitude, a rule followed by the snow cover. The slow melting of snow cover determined, in the middle of the twentieth century, "the most important condition in the development of mountain resorts globally, inducing a real tourist boom (asserts the engineering of ski and other winter sports), introducing winter tourism. (Surd, V., Bold, I., Zotic, V., Chira, C., 2005)

A specific concept for tourism is represented by tourism planning. Tourism planning can be defined as "a dynamic and complex process of organizing the tourist space", by designing new tourist facilities, by reconditioning the existing ones and resizing them in relation to the tourist demand. Tourism planning is also responsible for the economic profitability of the tourist activity, given the relations between the environment and the human communities, as well as the factors that have an impact on these relations. According to tourism planning, the first tourist centers that favored the practice of winter sports, started from the existing villages located at average altitude. The existence of these arrangements favored the formation of small resorts, being completed by summer tourist activities, by the attraction of tourists for sports in the winter season. Consequently, the first hotels appear and investment is made in mechanical means of access to ensure access to the ski areas.

The first Winter Olympics, organized in 1924 in Chamonix, also involved the achievement of the first complex planning, characteristic of a mountain resort in the current acceptance of the notion; in 1928 the first international alpine skiing competitions took place, and in 1936, during the Olympic Games in Garmisch Partenkirchen, alpine skiing appeared as an Olympic event. A special aspect in the evolution of the tourism planning specific to alpine skiing, is the expansion in altitude of this sport, which also determined the extension in the territory of the arrangements outside the perimeter of the resorts. The increase of accessibility and, implicitly, of the demand for the forms of mountain tourism has led to an increase of the 
skiing season and implicitly to an expansion to higher altitudes of the facilities. In the first half of the last century, low-altitude resorts dominated - below $1000 \mathrm{~m}$ and with complex activities, which were considered first generation resorts.

Starting with the middle of the last century, second generation resorts were formed, also located at altitudes of up to $1000 \mathrm{~m}$, but in virgin areas, towards the upper limit of the forests. The development of these resorts was aimed at a rational planning of the perimeter, characterized by "precise functional zones, direct access to accommodation units from the ski areas, the exclusion of roads and car parks from the perimeter of sports."

The third generation of ski resorts, built after 1960, involved the development of real ski resorts in Europe, resorts that integrate winter sports and are set up as complexes with tens of thousands of accommodation, at altitudes of over $2000 \mathrm{~m}$. Most of the times, these generations of tourism planning follow one another in altitude and create "anthropic landscape-functional complexes of a great diversity".

The planning of the ski area is an integral part of the process of planning the mountain space, a key point in creating a tourist resort for winter sports. A number of parameters are considered regarding the planning of the ski area: the number of ski slopes, the length of the ski slopes (in total and by categories), the transport of tourists to the ski slopes through cable transport facilities (chairlift, cable car, ski lifts), as well as auxiliary equipment (artificial snow cannons). (Erdeli, G., Gheroghilas, A., 2008)

In the arrangement of the slopes, the configuration of the landforms is also taken into account, the guidelines being given by the natural conditions, but also by the economic situation of the region. The slopes can therefore be differentiated depending on the concentration of the facilities, their distribution being made around the massifs, inside them or along the valleys. A differentiation is also made depending on the location of the resort from the massif, being placed on the periphery, linear, following the natural corridors or in the terminal area, at height or at the base beyond the limits of human settlements. (Gingulescu, D.M., 2010)

Another form of slope classification is given by the degree of difficulty. Both in Romania and in Bulgaria, in the ski resorts, the difficulty of the slopes is regulated, the classification by degrees of difficulty being the following: green - very easy slope (ski slope with average slope inclination of maximum 10\%, width of minimum $30 \mathrm{~m}$ and a level difference of maximum $50 \mathrm{~m}$ ), blue - easy slope (ski slope with average slope inclination of maximum 20\%, width of minimum $30 \mathrm{~m}$ and a level difference of maximum $200 \mathrm{~m}$ ), red medium slope ( ski slope with an average slope of up to $30 \%$, width of at least $20 \mathrm{~m}$ and a level difference of at most $500 \mathrm{~m}$ ), black - difficult slope (ski slope with an average slope of up to $40 \%$, width of minimum $20 \mathrm{~m}$ and a level difference of maximum $50 \mathrm{~m}$ ).

In addition to the classification according to the degree of difficulty, the ski areas can also be classified according to the location and the existing relationships in their main elements, being outlined the following models (Figure 1).

Model 1 is specific to small slopes, the case of slopes bordered at the bottom by a road or a small tourist resort, the cable transport being on the same route as the slope.

Model 2 is used when parallel slopes operating separately are planned along this communication path.

Model 3 is used when considering the arrangement of two or more slopes from several sectors, arranged one in the extension of the other. In this context, cable transport is provided by two different installations, a slope being served by a chairlift and a ski lift; it is possible to use a single cable transport on both sides.

Model 4 is specific to an area in which several valleys and slopes have an inclination that converge in one depression, the slopes having different degrees of difficulty. Serving tourists is done in a center equipped with a well-developed infrastructure.

For Model 5, only one cable line has been designed for several slopes with different degrees of difficulty, so it is absolutely necessary to properly dimension the conveyor line.

Model 6 is similar to model 5, but the planning of the slopes is more elaborate.

In the case of Model 7, the slopes are placed on either side of the access roads to them.

Model 8 is specific to a large layout, which includes everything that exists in the area, being in fact a combination of previous models. The specific infrastructure of this model is complex and is often used in most ski areas in Europe with an old tradition in winter sports. However, these models can encounter numerous changes that are dependent on the configuration of the landforms. These European models are also present in Romania, and the existing ski areas have developed around the already existing mountain resorts. 


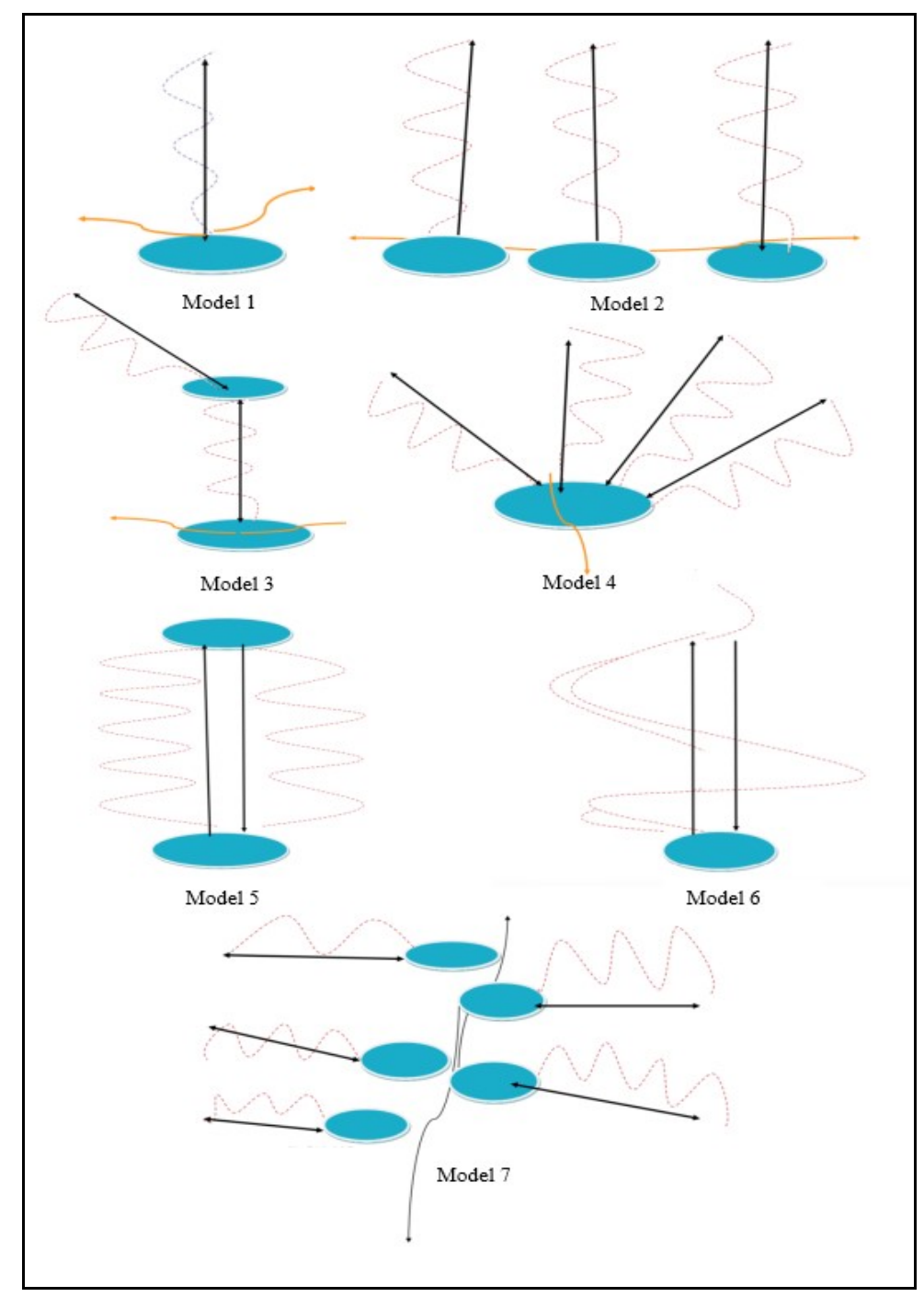

Figure 1. Classification of ski areas

Source: Gingulescu, D.M., 2010

\section{Results}

\subsection{Ski Resorts In Romania (Prahova Valley)}

Bucegi Mountains and the Prahova Valley were the first tourist region of the country and the cradle of Romanian tourism. However, we can only talk about winter sports in Romania since the 19th century. The first ski competitions also started in the 19th century. In Romania, the special natural conditions and the special tourist potential have determined the development at international level, especially of three fundamental resorts: Poiana Brașov, Sinaia, Predeal, which "concentrates on an area of about $150 \mathrm{~km}$, $63 \%$ of the existing accommodation capacities in the Romanian mountain resorts, $70 \%$ of the total slopes and cable installations and $40 \%$ of the tourist traffic in the mountain area, respectively $52 \%$ of the arrivals of foreign tourists ". Regarding the optimal capacity of the slope (number of people/hour) there is a direct proportionality between the total number of slopes and tourist circulation: Sinaia (7740 people/hour), Poiana Brașov (5280 people/hour), Predeal (4140 people/hour). At the same time, this complex of resorts has an offer that satisfies the requirements of international tourism in terms of winter sports. However, there are also a number of deficiencies regarding the relatively low diversification of accommodation and public catering units, the inadequacy of leisure, cultural and sports facilities, the lack of competitiveness in terms of skiing, which is particularly valuable in terms of length, width and variety of the slopes, insufficient capacity of the mechanical installations or faulty maintenance of the ski slopes.

At the end of the 19th century, Sinaia became a national and European tourist center, manifesting itself by the founding in 1903 of the first great Society of Romanian Tourists. The construction of the Caraiman (1881) or Palas hotels (1911) is also linked to these beginnings of tourism. Up on the mountain there are the first tourist chalets, the first being Vârful cu For, Omu refuge or Schiell house. Sinaia had become a luxury holiday resort that offered tourists in the first half of the last century 10 hotels, 55 large villas, 50 medium-sized villas and 60 country houses, two casinos, hydrotherapy baths, a zoo, carriages for walks, horse-riding centers and riding school, breweries, confectioneries and shops, as well as a promenade park. All these aspects gave it the name of Pearl of the Carpathians. 
Sinaia is a central resort, located on the upper Prahova River Valley, being planned in the form of a large amphitheater at the foot of the Bucegi Mountains, extending in the North, to the place called Gura Pădurii, and to the South to beyond the Izvorului Dorului Valley, where in the ninth decade of this century the Plateau Izvor neighborhood was built. In addition to the winter sports facilities, Sinaia resort allows the practice of other forms of tourism due to the existence in the perimeter of the resort of sulfurous mineral sources, bicarbonate, calcium, magnesium, oligominerals springs. Sinaia resort has a casino, tennis courts and indoor swimming pools, maintenance and conference rooms, indoor swimming pools, which complete the leisure offer.

The ski area of Sinaia currently has the status of tourist and balneo-climatic resort of national interest, encompassing $22 \mathrm{~km}$ of slopes that run on several areas: Dorului Valley, Brazi Valley, Valea lui Carp, Valea Soarelui, with an altitude of the ski area that starts from $860 \mathrm{~m}$ to $2000 \mathrm{~m}$. Currently, Sinaia is also an important tourist and conference center for international and national conferences. The ski area of Sinaia is represented by 16 approved ski slopes ( $25 \mathrm{~km}$ of slope), served by cable car, 2 chairlifts, ski lifts and babyski Pârtia Nouă, gondola and a bobsled slope with a length of $1500 \mathrm{~m}$. Undoubtedly, here we find the most complex and complete ski area in the country, the main advantage being the level difference. Sinaia is "the only winter resort in Romania that has slopes arranged at almost 1000 meters altitude, starting with Pârtia Nouă, whose arrival is at the starting station of the Gondola and ending with the altitude slopes of Valea Soarelui and Valea Dorului. Sinaia is the resort with the longest winter season; the ski area matches model 5 presented above, as all the approved slopes reach $1400 \mathrm{~m}$ from where the tourists can ski on each of them.

Poiana Brașov has been documented since 1427 in terms of shepherding activities that took place in this territory. Later, the area began to be frequented for hiking and winter sports. Located at the foot of the Postavaru Massif, Poiana Brasov is often regarded as one of the internationally renowned attractions, a modern tourist resort. Since ancient times, Poiana Brașov has attracted both mountain hiking enthusiasts and winter sports enthusiasts.

In 1924, the current "Ruia" chalet was put into operation, considered the first hotel in Poiana, and later several smaller buildings and houses appeared. Two slopes were available: "the so-called slope on the valley with telephone poles (the actual Sulinar Slope) for advanced skiers and a family slope over Crucur and Drester to Poiana, then extended with Drumul lui Gust, to the city." In 1906, Poiana Brașov was declared the first ski resort, also taking place here the first ski competition in Romania. In 1951, on the occasion of the International Winter Students Games, a modern hotel and the first cable car connecting Poiana Brașov to Postăvarul, with a length of 2150 meters, were put into use.

The ski area in Poiana Brașov has 9 ski slopes, being equipped with two cable car lines and one gondola that ensures the access of tourists to the peaks of Postavaru Mountain, to which are added, seasonally, several ski lift lines. This resort differs from the other resorts by the fact that it is located in the vicinity of a large city - Brasov -, being connected both by road and by cable transport. The domain from Poiana Brasov falls under the incidence of model 3 , previously presented.

Predeal is the city in Romania located at the highest altitude $(1030-1110 \mathrm{~m})$, at the foot of the Bucegi Mountains. Currently, Predeal is known especially for winter sports, offering the possibility to ski on the 8 alpine ski slopes with different degrees of difficulty; in the summer season, the mountains around the city offer the possibility of unforgettable hikes and routes of different degrees of difficulty.

The first historical documents confirm that in the Predeal area, in Brașov there was in the 1880s a society for skiers from the region, so that in 1892 a group of skiers led by Carol Ganzert went to Clăbucet. Starting with the 1900s, skiing in Predeal develops from two directions: from Brașov, where the Saxons and Szeklers came to Predeal to ski on Clabucet and Poiana Secuilor and from Bucharest, where the population of the capital that frequented the resorts in Switzerland, came to Predeal for skiing. In 1903 a ski competition was organized at the Susai chalet, and in 1905 a ski competition was held at "Piatra Mare".

In 1933, new slopes were opened and the Cioplea ski jump was inaugurated. In the same year, the National Academy for Physical Education and Sports in Bucharest organizes in Predeal the first training courses for ski instructors. In Predeal, the ski area starts from the resort located at over $1000 \mathrm{~m}$ altitude. The road crosses the resort, with accommodation units on either side, with a higher share on the east side where the railway line is located. Here the endowments of the ski area encounters 14 ski slopes of different degrees of difficulty, the skiers being served by means of cable transport: chairlift, ski lift. The ski area from Predeal falls under the incidence of model 2 presented in the previous chapter of the paper.

\subsection{Ski Resorts In Bulgaria}

Bulgaria's ski areas have been heavily modernized over the last two decades, with slopes for both beginners and experienced skiers. There are $210 \mathrm{~km}$ of ski slopes in Bulgaria and 90\% of Bulgarians prefer domestic tourism. In Bulgaria there are 40 mountain groups with potential and tourist exploitation, and their hot springs are also a main factor of winter tourism. The best known ski areas are Bansko, with a total of 75 $\mathrm{km}$ of slopes and Borovets, with a total of $52 \mathrm{~km}$ of slopes, to which is added the one in Pamporovo. The modernized area of Bansko has become over time one of the most important centers of winter sports in Eastern Europe. The Bulgarian model involves a strong launch of the three most important resorts on the 
international tourism market. The equipment of these resorts is similar to those in the Alps, the planning being made in collaboration with French or Austrian companies. In order to increase the notoriety of these resorts, Bulgaria offered to host stages and ski competitions from the European Cup and World Cup.

Bansko Resort, the most important ski resort in Bulgaria, is located at the foot of the Pirin Mountains, in the eastern part where the highest peaks are found, near the Glazane River and only $160 \mathrm{~km}$ from Sofia. The town of Bansko is located at an altitude of $925 \mathrm{~m}$, while the slopes are located at an altitude of 2000-2600m. Although Bansko began to develop as a ski resort about 30 years ago, foreign investment began to flow after the 2000s, thanks to fiscal facilities provided by the Bulgarian government. In the international arrangement of the slopes, huge sums were invested in the construction of accommodation units, the real estate market flourishing rapidly. Tourism therefore represents $60 \%$ of the economy of Bansko Municipality, which is divided into 5 areas: the old quarter considered an architectural masterpiece of the Renaissance, the transitional area, the hotel area, the area of houses and agricultural land. Bansko is connected to the ski resort at the top of the mountain by a $16 \mathrm{~km}$ road, and a total length of funiculars and lifts that reaches $26 \mathrm{~km}$.

Known internationally as the "Bansko Ski Area", this resort is one of the most famous and modern ski resorts in Eastern Europe, with 16 cable facilities serving various slopes with a combined length of $48 \mathrm{~km}$ to an altitude of $2560 \mathrm{~m}$. The resort has two large ski resorts, namely Chalin Valog (1100-1600m) and Shiligarnika (1700-2500m), both easily accessible and located about a 25 -minute walk from the gondola that starts right from the center of Bansko. The total length of the slopes is $70 \mathrm{~km}$, being divided proportionally: $30 \%$ slopes for beginners, $45 \%$ slopes for advanced and $25 \%$ slopes for experts. The snow conditions, but also the existence of the cannons allow the ski season to last from December to May. Moreover, snowboard lovers can enjoy the first funpark in the Balkans, where all lovers of extreme sports meet and where competitions are organized daily on the new slope of Shiligarnika. From the point of view of transport, in Bansko we find an 8-seater gondola, 3-seater chairlifts and 7 ski lifts. Also here we meet slalom slopes, huge slalom slopes and cross-country ski slopes with a length of $5 \mathrm{~km}$.

Borovets is the oldest ski resort in Bulgaria, with a history dating back to the late nineteenth century (1896), being developed as a hunting ground for kings. Borovets is considered one of the largest and most modern resorts in Bulgaria, being located east of Rila, at the foot of Mousala Mountain, and is easily accessible being just $72 \mathrm{~km}$ away from the capital Sofia. It is located at an altitude of $1390 \mathrm{~m}$ above sea level, being the ideal destination for recreation and relaxation. The climate is considered to be particularly healthy, with the winter season lasting from mid-December to April. Skiers enjoy $45 \mathrm{~km}$ of slopes, which are grouped into 3 regions: Sitniakovo-Martinovi Baraki, Markudjik and Yastrebets. The best slopes are located in the latter area, where most of the winter competitions are organized, the area being also twice the host of the Alpine Ski World Cup. Borovets also has the best biathlon track in Europe.

Markudjik Ski Center is ideal for freestyle lovers, thanks to the snow cover that exceeds 2 meters in mid-winter.The highest ski slope reaching an altitude of $2560 \mathrm{~m}$, the longest ski trail having a length of $12 \mathrm{~km}$ (Mousala Pathway). The ski area is served by a cable car with a capacity of 6 people, 1 chairlift, 2 ski lifts, children ski lifts, the slopes being divided into different degrees of difficulty: beginner, intermediate or advanced.

Pamporovo is a modern resort, located in the heart of the Rhodope Mountains, at the base of Mount Orpheus. Being the most southern mountain resort in Europe, it is also considered the sunniest mountain resort in Bulgaria, with excellent snow throughout the season. The gentle profile of the mountain makes its slopes ideal for beginners. This resort is located in the south of the Rhodope Mountains, at $1620 \mathrm{~m}$ above sea level, the Snejanka peak, the highest in the area (1928m) being only a few hundred meters above the resort. The first villas began to be built in 1961, the resort being named Vasil Kolarov. Once it was found that the snow lasted 5 months a year, the resort was redesigned to promote winter sports, later being renamed Pamporovo and included in the list of the International Ski Federation. In 1972, the first Balkan ski resort was organized in Pamporovo. The development of the resort continued with the construction of the ski lift and the tourist heliport, along with numerous other accommodation units.

The resort currently has $55 \mathrm{~km}$ of alpine ski slopes and $38 \mathrm{~km}$ of cross-country ski runs served by 18 lifts with a total capacity of 13000 people per hour. The aim is to develop the resort to Mount Perelik, by expanding the ski area. In fact, in 2010 an additional customs check point was opened between Bulgaria and Greece, just a half-hour drive from Pamporovo, drawing public attention to the fact that Pamporovo is the only resort in Europe that allows passing from winter sports to summer sports in such a short time. The ski area of Pamporovo is served by 5 chairlifts and 9 cable cars. In this resort we also find three cross-country slopes, with a total length of $40 \mathrm{~km}$. Moreover, the Pamporovo resort is a ski resort suitable for beginners. The total length of the slope with medium difficulty is about $20 \mathrm{~km}$, the skiers going with the chairlift from Malina station to the top of Snejanka peak. For advanced skiers, most of the slopes start from the top of the mountain, where the Television Tower is located. The Pamporovo estate is built according to model 1, presented in the previous chapter of the paper. 


\section{Conclusions}

Due to the significant and rapid growth of tourism in recent times, there is a need for a better understanding of its influence on the national economy of countries. Tourism influences both the economy of a country, as well as the natural and anthropic environment, the host populations, but also the tourists. In this context, mountain tourism has developed seriously in recent decades, and not only during the winter season, when the winter sports season turns mountain resorts into tourist favorite destinations. It is true that mountain tourism has developed over time, based on major investments, mainly due to the growing demand for accommodation and winter sports. Investments were thus naturally concentrated in areas that perfectly combined natural, economic and social conditions. For mountain tourism, the natural potential is essential, represented by the mountain complex that offers spectacular landscapes and specific conditions for winter sports.

Undoubtedly, the most competitive and sought-after mountain resorts are specific to solid national economies, in the European Alpine countries (France, Switzerland, Austria, Italy, Germany), in the Scandinavian countries or in the United States and Canada. States such as Romania or Bulgaria, based on their natural potential, have tried to become "interesting players" on the international mountain tourism market. Thus, in Europe, along with the large concentrations of mountain resorts in the Alps, Pyrenees and Scandinavia, tourist complexes are developing in the Carpathian Mountains and the Balkan-Rhodope-Rila Mountains. That is the reason this paper wanted to highlight the comparative evolution of ski tourism in two less famous tourist destinations, but at least as interesting, related to Romania and its Bulgarian neighbors.

The core of the research focuses on the tourism planning specific to winter sports in Romania and Bulgaria, detailing the tourism specific to alpine skiing in Poiana Brașov, Predeal and Sinaia (Romania), Bansko, Borovets and Pamporovo (Bulgaria).

In the same time, the Alps remains the main mountain destination of the world, but the mountain area of Europe, including the Carpathians and the Balkan Mountains stands out from a tourist point of view, compared to other mountain areas of the world, with a rich landscape the immense cultural historical one.

The Carpathians, although not as high as the Alpine one, also has an excellent natural and tourist potential. The beauty of the landscapes, the richness of the karst phenomena (caves, gorges, gorges), of the mineral and thermal springs, the hydrographic network as well as the multitude of forests in the Carpathians allowed their tourist capitalization especially in the Romanian Carpathians. Similar tourist resources are also found in the Balkan Mountains, making Bulgaria a favorite destination for an increasing number of tourists. The mountain resorts on Prahova Valley (Sinaia, Busteni, Azuga, Predeal), the most famous and sought after resorts in the Carpathians, along with the famous Poiana Brasov, are often too small during peak periods. The most popular resorts in Bulgaria, Bansko, Borovets and Pamporovo, rebuilt through massive investments of the last decade, make a fierce competition to the Romanians in Eastern Europe and also on the international mountain tourism market.

Future studies will be able to analyze this competition and observe the impact of investments in tourism infrastructure related to winter sports, on indicators of tourism circulation, such as the number of arrivals or their classification according to origin (domestic tourists or international tourists).

\section{References}

1. Cândea, M., Erdeli, G., Simon, T., Peptenatu, D., Potenţialul turistic al României și amenajarea turistică a spaţiului, Editura Universitară, Bucureşti, 2003, p.13

2. Ciangă, N., Amenajare turistică - Suport de curs, Universitatea „Babeș-Bolyai” Cluj Napoca, Facultatea de Geografie, 2015, Accesat la: https://www.academia.edu/28290726/Amenajare_turistica_Cianga_Nicolae_modulul_I_II

3. Dinu, M., Geografia turismului, Editura Didactica si pedagocica, Bucuresti, 2002, pag. 110.

4. Erdeli, G., Gheroghilas, A., Amenajări turistice, Editura Universitară, București, 2008.

5. Gingulescu, D.M., Potențialul schiabil al României, Universitatea Babes Bolyai, Cluj Napoca, 2010

6. Sochircă, V., Iațu, C., Considerații conceptuale și metode geografice de analiză a fenomenului touristic, Revista Științifică a Universității de Stat din Moldova, 2013, nr. 6(66) 134, Accesat la: http://studiamsu.eu/wp-content/uploads/22.-p.134-140.pdf

7. Susanu, I.O., Marketing turistic, Ed. Didactică și Pedagogică, București, 2007

8. Surd, V., Bold, I., Zotic, V., Chira, C., Amenajarea teritoriului si a infrastructurii tehni-ce, Edit. Presa Univ. Clujeana, Cluj Napoca (capitolul "Amenajarea turistica", 2005, p. 324-340

9. Tribe, J., The Economics of Recreation, Leisure and Tourism, 5th edition, Ed. Routledge, New York, 2016

10. Ungureanu, A., The importance of Romanian Mountain Tourism for the National Economy, Economics of Agriculture $3 / 2015$

11. Bansko Domeniul Schiabil, n.a., Accesat la: https://www.snowtrex.ro/bulgaria/bansko/domeniu-schiabil.html

12. Borovets Domeniul Schiabil, n.a., Accesat la: https://www.snowtrex.ro/bulgaria/borovets/domeniu-schiabil.html

13. Bulgaria, Basnko, n.a., Accesat la: https://www.skimania.ro/schi-Bulgaria-statiune-Bansko-246.html

14. Bulgaria, Borovets, n.a., Accesat la: https://bulgariaschi.ro/borovets/

15. Bulgaria Domenii schiabile, n.a. Accesat la: https://www.snowtrex.ro/bulgaria/regiuni_de_schi.html

16. Domeniul schiabil Sinaia, n.a., Accesat la: https://palacesinaia.ro/palace/domeniul-schiabil-sinaia/

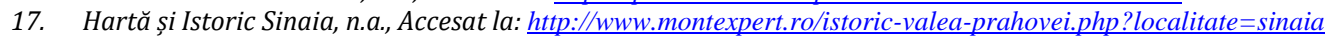

18. Istoria cabanei Postăvaru, n.a., Accesat la: https://cabanapostavaru.ro/istorie-cabana-postavaru

19. Istoria schiului predelean, n.a., Accesat la: http://www.predeal.ro/ro/istoria-schiului-predelean.html

20. Istoria și evoluția schiului, 2019, Accesat la: https://www.turnulsfatului.ro/2019/12/03/istoria-si-evolutia-schiului-159591

21. Istoria stațiunii Poiana Brașov, 2015, Accesat la: https://www.rizzohotel.ro/istoria-statiunii-poiana-brasov/

22. Osho, Mica Elveția, n.a., Accesat la: https://www.literaturadeazi.ro/rubrici/recomand-romania/mica-elvetie-42896

23. Pamporovo Domeniu Schiabil, Accesat la: https://www.snowtrex.ro/bulgaria/pamporovo/domeniu-schiabil.html

24. Pârtiile de schi din stațiunea Predeal, n.a., Accesat la: https://blog.travelminit.ro/partiile-de-schi-din-statiunea-predeal/

25. Pârtii de ski, n.a., Accesat la: https://www.discoverpoiana.ro/ro/partii-schi-snowboard/

26. South East Tourism, n.a., Accesat la: https://investingintourism.com/southeast-europe-tourism/ 